\title{
EFFECT OF SHADING ON THE PERFORMANCE AND PRODUCTIVITY OF DOUBLE SLOPE SOLAR STILL UNDER CLIMATIC CONDITIONS OF EGYPT
}

\author{
El-Sheikh, I. H.*
}

\section{ABSTRACT}

The present work aims to study the possibility of enhancing and increasing the productivity of fresh water from the double slope solar still by improving the performance of its condenser. Single basin asymmetrical double sloped solar still was employed during this study. The study was carried out on the roof of Agricultural Engineering Department, Suez Canal University, Ismailia Governorate (Latitude and Longitude angles, respectively, are $30.62^{\circ} \mathrm{N}$ and $32.27^{\circ} \mathrm{E}$, and mean altitude above the sea level is $20 \mathrm{~m}$ ). The solar still consists mainly of a rectangular iron basin $(1.80 \times 0.80 \mathrm{~m})$ and $0.10 \mathrm{~m}$ deep. The bottom frame was constructed of wood and insulated by $2 \mathrm{~cm}$ thick of rock wool. The outer walls of the bottom frame were insulated with $7 \mathrm{~cm}$ thick of foam. The condensing zone consists of two inclined surfaces. The first inclined surface (which has the area of $1.46 \times 1.05 \mathrm{~m}^{2}$ ) covered with glass sheet (3 mm thick) to transmit the maximum possible of solar radiation flux incident on it. It was orientated to face the south direction with an inclination angle of $20^{\circ}$. The second inclined surface (which has the area of $1.05 \times 0.83 \mathrm{~m}^{2}$ ) covered with the same material and the same thickness. It was orientated to face the north direction with an inclination angle of $30^{\circ}$. Two configurations of experiments were performed. Firstly, studying the thermal performance of solar still under local climatic conditions. Secondly, exam lowering the northern glass cover temperature by shading it. This procedure lowered the high temperature of the northern cover, thus the temperature difference between water and northern cover was increased. The solar radiation intensity, wind speed, ambient temperature, amount of fresh water productivity and temperature of other components of the solar still were continuously measured.

\footnotetext{
*Associate Prof. of Agric. Eng. Dep., Fac. of Agric., Suez Canal Univ., 41522 Ismailia, Egypt.
} 
The experimental results revealed that, the daily average productivity of fresh water during the first and second configurations was found to be 2.9 and $3.3 \mathrm{l} / \mathrm{d}$, respectively, with an increasing of $13.79 \%$. The maximum values of heat transfer coefficient inside the solar still were 2.2, 7.5 and $33.3 \mathrm{~W} / \mathrm{m}^{2} \mathrm{~K}$ for convective, radiative, and evaporative coefficients, respectively. Because of the evaporative heat transfer coefficient strongly depends on the operating water temperature it was had the highest value. It was also found that, the maximum amount of heat losses that occur in the solar still was the radiation and convection heat transfer from glass to ambient air.

\section{INTRODUCTION}

$\mathrm{n}$ the last 40 years, the problem of freshwater shortage has been one
of the main challenges in the world. Desalination powered by
renewable energies can be an ideal solution for some small communities where an affordable fossil fuel supply for desalination is unavailable (Gracia-Rodriguez, 2004). Obtaining potable water through solar stills is one of the thermal applications harnessing the solar energy, which is viable and economical. Solar distillation works on the basic principle where the solar radiation from the sun gradually raises the temperature of the water inside a closed environment at a temperature higher than the ambient resulting in the process of evaporation followed by condensation on the slanted glass surface and collected through vents. It has been shown that the solar desalination remains the most favorable process for the supplying of water to small communities in remote villages (Boukar and Harim, 2003). The thermal efficiency of the simple solar still, in terms of daily production per unit area can be increased by various passive methods. Fath (1998) indicated that a combination of different design, operational and environmental parameters should be considered to improve the still performance. These parameters include: increasing basin temperature, evaporation and condensation surface areas, decreasing cover temperature, minimizing basin and sides heat losses and utilization of the shaded zone. These parameters could be considered without losing the credit of still simplicity in design and operation and its low cost. Two configurations 
were proposed for basin type stills: these are single slope and double slope. The maximum input radiation may be higher in a double-slope still, while the single slope has fewer convection and radiation losses and its shaded region may be utilized for additional condensation (Fath and Hosny, 2002). There are two types of double-slope still: symmetrical and asymmetrical stills. Al-Hayek and Badran (2004) obtained 20\% higher distilled water from an asymmetric greenhouse type solar still in comparison to symmetric greenhouse type solar still. Kabeel et al. (2014) studied the design modification of a single basin solar still to improve the solar still performance through increasing the productivity of distilled water. The experimental attempts are made to enhance the solar still productivity by integrating the still basin with external condenser. The results show that integrating the solar still with external condenser increases the distillate water yield by about $53.2 \%$. Some research works (Zeroual et al., 2011) were carried out to enhance the condensation process by cooling the outer or inner surface areas of solar still covers. The authors used shading screen and water flow to cool the covers of the double slope solar still. A productivity improvement of $11.82 \%$ was achieved using shading screen as compared with water flow usage. In another work, a solar fan was installed in the cover of a pyramid shape solar still in Jordan (Taamneh and Taamneh, 2012) to circulate and remove humid air above the basin water to increase the amount of evaporation and cool the inner cover's area. The productivity was about $25 \%$ higher than the conventional type. The effect of adding a passive condenser on the performance of the single-slope basin type solar still was studied by few authors. A single-basin-type solar still was investigated experimentally by El-Bahi and Inan (1999). Their solar still yielded a daily output of up to $7 \mathrm{~L} / \mathrm{m}^{2}$ with efficiency of $75 \%$ during the summer months. The solar still operated without a condenser yielded an efficiency of 70\%. Rajaseenivasan et al. (2013) tested various different wick and porous materials like black cotton cloth, jute cloth, waste cotton pieces, clay pots facing up and down and mild steel pieces in double basin and single basin solar still. They found that, the double-basin solar still with mild steel plates had higher productivity as compared with other 
materials. A single basin solar still is a simple device to produce drinking water from easily available saline water. A lot of research work is undertaken to improve the productivity of the still. Heat transfer in a solar still mainly depends on the difference in temperature between the evaporative water surface and the condensing surface. The main adjective of the present work was attempted to enhance the yield of the solar still by improving the thermal performance of its condenser. This was achieved by shading the north glass cover.

\section{MATERIALS AND METHODS}

Asymmetrical double sloped solar still was designed, installed and tested on the roof of Agricultural Engineering Department, Faculty of Agriculture, Suez Canal University (Latitude and Longitude angles, respectively, are $30.62^{\circ} \mathrm{N}$ and $32.27^{\circ} \mathrm{E}$, and mean altitude above the sea level is $5 \mathrm{~m}$ ). It was placed on the south-north direction in order to phase the southern direction and receive the maximum solar radiation. As shown in Fig. (1), the solar still is mainly consisted of a rectangular galvanized water basin having gross dimensions of $180 \mathrm{~cm}$ long, $80 \mathrm{~cm}$, and $10 \mathrm{~cm}$ deep. It absorbs the incident solar radiation that is transmitted through the glass cover. To prevent or minimize the heat losses from the back and the sides of the galvanized basin, the basin was fitted inside a wooden frame of an identical shape, but of a slightly larger size. The gaps between the wooden and galvanized of vertical walls basin were packed with $70 \mathrm{~mm}$ thick foam $\left(\mathrm{k}=0.04 \mathrm{Wm}^{-1} \mathrm{~K}^{-1}\right)$ and the bottom insulated by $2 \mathrm{~mm}$ thick of rock wool $\left(\mathrm{k}=0.0346 \mathrm{Wm}^{-1} \mathrm{~K}^{-1}\right)$. The condensing zone consists of two inclined surfaces. The front inclined surface was covered with glass sheet ( $3 \mathrm{~mm}$ thick) that having grossed dimensions of $146 \mathrm{~cm}$ long and $105 \mathrm{~cm}$ to transmit the maximum possible solar radiation flux incident on it. It was orientated to face the south direction with an inclination angle of $20^{\circ}$. The back inclined surface was also covered with glass sheet $(3 \mathrm{~mm}$ thick) which having gross dimensions of $105 \mathrm{~cm}$ long and $83 \mathrm{~cm}$. It was orientated to face the north direction with an inclination angle of $30^{\circ}$. Utmost care was taken to make the entire system vapor tight by using silicon sealant. 

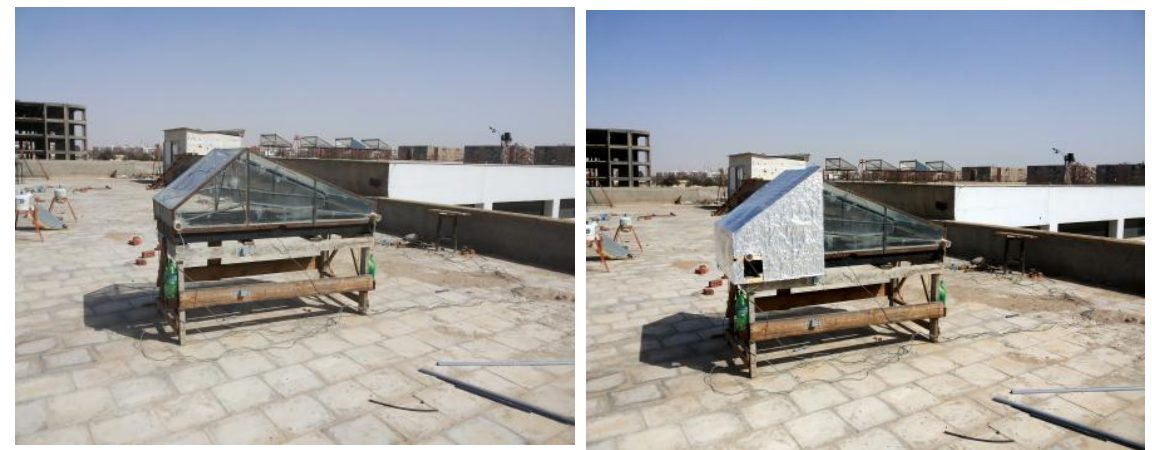

Fig. (1): Asymmetrical double-slope solar still with and without shading.

A trough running along the bottom sides of the two inclined surfaces ensures the collection of the distilled fresh water and leads it to the distilled water-collecting vessel. Some other collecting channels were positioned on the vertical walls for collecting the condensed water. To reduce the somewhat high temperature of the northern glass cover, and consequently, increasing the temperature difference between basin's water and glass cover, the northern glass cover was shaded with wooden box at a distance of $10 \mathrm{~cm}$ above the back glass cover of the solar still. Experimental work was carried out on successive days during August month of 2015 (from $5^{\text {th }}$ to $20^{\text {th }}$ of August). The experimental work started at 7.00 am and terminated at $7.00 \mathrm{pm}$ local time. Saline water $(30,000 \mathrm{ppm})$ was used as feed. The experimental procedure commenced by cleaning dust from the external glass covers and the collected water was measured each hour during the daylight-time. Meteorological station (Vantage Pro 2, Davis, USA) located beside the solar still (on the roof of the Agricultural Engineering Department) was used to measure different macroclimatic variables such as solar radiation flux incident on a horizontal surface (pyranometer), dry-bulb, wet-bulb, and dew-point air temperatures. Six thermocouples were functioned to measure the temperatures of inner and outer surfaces of northern and southern glass covers, vapour and water in the basin. These sensors were connected to a data-logger system (Lab-Jack logger, USA) to display and record the data during the experimental period. The data were also instantly displayed on the video screen and updated by a scan of all the sensors every 60 seconds. The means of 12 scans were taken and stored in the computer 
files every 5 minutes for 24 hours per day. All thermocouple sensors were calibrated with an electronic thermometer $\left(-10\right.$ up to $\left.100^{\circ} \mathrm{C}\right)$. Two configurations of experiments were performed. The first one was studied the thermal performance of solar still under local climatic conditions without shading technique. The second configurations was examined the thermal performance of the solar still with shading the back glass cover (northern glass cover).

\section{Thermal analysis}

\section{Internal heat transfer}

The internal heat transfer mode is the heat exchange from the basin water surface to the glass cover inside the still unit which governed by radiation, convection and evaporation. In this case, the basin water surface and the glass cover are considered as infinite parallel. Heat transfer occurs across humid area in the distillation unit by free convection caused by the effect of buoyancy due to density variation in the humid fluid, which occurs due to the temperature gradient in the fluid. Hence, the rate of heat transfer from the basin water surface to the glass cover by convection is the upward direction through the humid fluid and it can be estimated by the following equation (Tiwari et al., 2007):

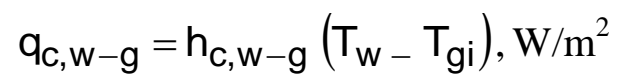

where, $q_{c, w-g}$ is the rate of heat transfer from the basin water surface to the glass cover by convection, $\mathrm{W} / \mathrm{m}^{2}, T_{w}$ is the basin water temperature in $\mathrm{K}, T_{g i}$ is the inner surface temperature of glass cover in $\mathrm{K}, h_{c, w-g}$ is the convective heat transfer coefficient from the basin water to glass cover, $\mathrm{W} / \mathrm{m}^{2} \mathrm{~K}$ and it can be calculated using the following equation (Dunkle, 1961):

$$
h_{c, w-g}=0.884\left[\left(T_{w}-T_{g i}\right)+\frac{\left(P_{w}-P_{g i}\right)\left(T_{w}+273\right)}{268.9 \times 10^{3}-P_{w}}\right]^{\frac{1}{3}}, W / m^{2} K
$$

where, $P_{w}$ is the partial saturated vapor pressure at basin water temperature in $\mathrm{N} / \mathrm{m}^{2}$ and $P_{g i}$ is the partial saturated vapor pressure at inner surface temperature of glass cover in $\mathrm{N} / \mathrm{m}^{2}$. 
The values of $P_{w}$ and $P_{g}$ (for temperature ranged between 10 and $90^{\circ} \mathrm{C}$ ) can be computed as follows (Fernandez and Chargoy, 1990):

$$
\begin{array}{ll}
P_{w}=\exp \left(25.317-\frac{5144}{T_{w}+273}\right), & N / m^{2} \\
P_{g i}=\exp \left(25.317-\frac{5144}{T_{g i}+273}\right), & N / m^{2}
\end{array}
$$

The general equation for the rate of evaporative heat transfer between basin water to glass cover $q_{e, w-g}$ is given by Velmurugan and Srithar (2007)

$$
q_{e, w-g}=h_{e, w-g}\left(T_{w}-T_{g i}\right), \quad W / m^{2}
$$

where $q_{e, w-g}$ is the rate of evaporative heat transfer between basin water and glass cover, $\mathrm{W} / \mathrm{m}^{2}, h_{e, w-g}$ is the evaporative heat transfer coefficient from the basin water to the glass cover, $\mathrm{W} / \mathrm{m}^{2}$ and can calculated by Cooper (1973) as:

$$
h_{e, w-g}=16.273 \times 10^{-3} h_{c, w-g} \frac{P_{w}-P_{g i}}{T_{w}-T_{g i}}, \quad W^{2} K(6)
$$

The rate of radiative heat transfer from the basin water to glass cover $q_{r, w-g}$ is given by Tiwari and Tiwari (2008) as:

$$
\mathrm{q}_{r, w-g}=h_{r, w-g}\left(T_{w}-T_{g i}\right), \quad W / m^{2}
$$

Where $h_{r, w-g}$ is the radiative heat transfer coefficient between basin water to glass and cab be estimated by Tiwari (2002) as:

$$
\mathrm{h}_{\mathrm{r}, \mathrm{w}-\mathrm{g}}=\varepsilon_{\text {eff }} \sigma\left[\left(\mathrm{T}_{\mathrm{w}}+273\right)^{2}+\left(\mathrm{T}_{\mathrm{gi}}+273\right)^{2}\right]\left[\mathrm{T}_{\mathrm{w}}+\mathrm{T}_{\mathrm{gi}}+546\right], \mathrm{W} / \mathrm{m}^{2} \mathrm{~K}(8)
$$

Where $\sigma$ is the Stefan-Boltzmann constant $\left(5.667 \times 10^{-8} \mathrm{~W} / \mathrm{m}^{2} \mathrm{~K}^{4}\right.$ and $\varepsilon_{\text {eff }}$ is the effective emittance between water and glass cover, it can be estimated using the following equation: 


$$
\varepsilon_{\mathrm{eff}}=\frac{1}{\left(\frac{1}{\varepsilon_{\mathrm{gi}}}\right)+\left(\frac{1}{\varepsilon_{\mathrm{w}}}-1\right)}, \text { decimal }
$$

Where, $\varepsilon_{g i}$, is the emissivity of the inner glass surface (0.85) and, $\varepsilon_{w}$, is the emissivity factor of basin water surface (0.96).

\section{External heat transfer}

The heat is lost from outer surface of the glass to atmosphere through convection and radiation modes. The glass and atmospheric temperatures are directly related to the performance of the solar still. The radiative heat transfer from the glass cover to the atmospheric air is given by Malik et al. (1982) as:

$$
\mathrm{q}_{\mathrm{r}, \mathrm{g}-\mathrm{a}}=\varepsilon_{\mathrm{go}} \sigma\left[\left(\mathrm{T}_{\mathrm{go}}+273\right)^{4}-\left(\mathrm{T}_{\text {sky }}+273\right)^{4}\right\rfloor, \mathrm{W} / \mathrm{m}^{2}
$$

where, $\varepsilon_{g o}$, is the emissivity of the outer glass surface (0.89) and, $T_{s k y}$, is the average sky temperature during the operating hours, it can be estimated using the following equation (Duffie and Beckman 2006):

$$
\mathrm{T}_{\text {sky }}=0.0552 \mathrm{~T}_{\mathrm{a}}^{1.5}, \quad \mathrm{~K}
$$

Where, $T_{a}$, is the ambient air temperature, $\mathrm{K}$. The convective heat transfer between glass cover and atmosphere is given by Malik et al. (1982) as follows:

$$
\mathrm{q}_{\mathrm{c}, \mathrm{g}-\mathrm{a}}=\mathrm{h}_{\mathrm{c}, \mathrm{g}-\mathrm{a}}\left(\mathrm{T}_{\mathrm{go}}-\mathrm{T}_{\mathrm{a}}\right), \quad \mathrm{W} / \mathrm{m}^{2}
$$

The convective heat transfer coefficient between glass cover and atmosphere, $h_{c, g-a}$, depends up on the prevailing wind speed, $w$, in $\mathrm{m} / \mathrm{s}$, it can estimated by McAdams (1954) as:

$$
h_{c, g-a}=5.7+3.8 w, \quad \mathrm{~W} / \mathrm{m}^{2} \mathrm{~K}
$$




\section{RESULTS AND DISCUSSION}

The temperature variations of different components of the conventional and shaded solar stills are plotted in Figs. (2) and (3), respectively. The temperatures have the same trend, as they increased gradually from early morning till reached the maximum values afternoon (at $13 \mathrm{~h}$ ), and then decrease with the time of day until approached the minimum value at sunset time when intensity of solar radiation and ambient air temperature decreased. It evidently revealed that, the temperatures of all the solar still components were higher than the ambient air temperatures. Because of the components have an ability of intercepting and converting solar radiation into thermal radiation (heat). It is also observed that, the temperatures of all the solar still components follow the same pattern because they are directly affected by the incoming solar radiation and atmospheric condition around the solar still. The obtained result also shows that, the inner surface of northern cover, inner surface of southern cover, basin water and vapour temperatures for the solar still operated without shading reached the maximum values of 53.9, 56.9, 63.0 and $68.1^{\circ} \mathrm{C}$, respectively. While these values for the solar still with shading technique, respectively were $56.0,60.0,64.9$ and $69.0^{\circ} \mathrm{C}$. It was also noticed that, the level of water temperature in the basin was higher than that of the ambient air that showed how much heat is trapped by the water to cause evaporation. Since the glass temperature is cooler, water vapor reaching it then cools down and condenses to form fresh water droplets which coalesces together to form liquid (fresh water) that flow down the slope into the channel. The hourly average volumetric rates of distilled water produced in both sides of the solar still operated without and with shading are presented in Figs. (4) and (5), respectively. As displayed by these figures, the production rate starts very slowly, due to the low level of solar radiation during the first three hours. Otherwise, the majority of solar radiation available inside the solar still in the morning was consumed to warm up the different components of solar still. It is also shown that, the maximum amount of production rate was achieved afternoon (at 13h), and decreased after this time. 


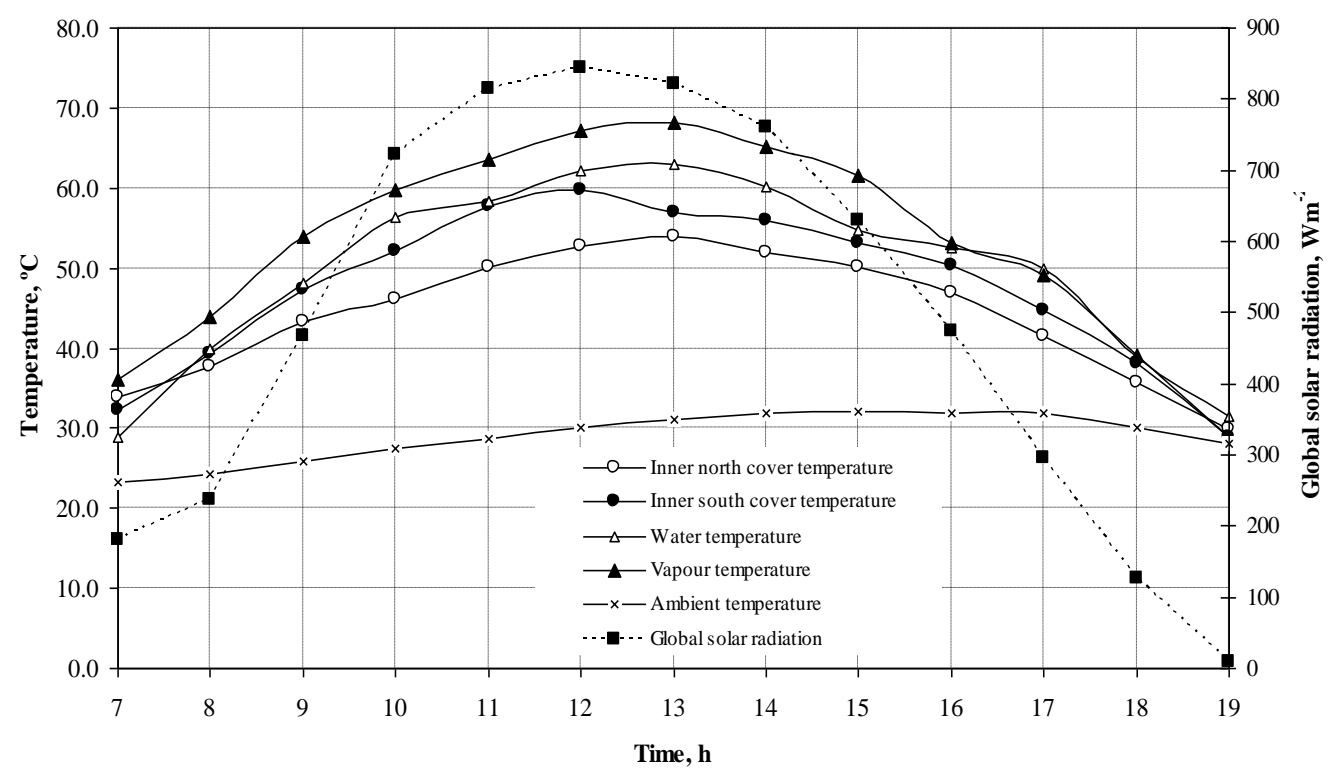

Fig. (2): Solar intensity and temperature variations of different components of solar still without shading.

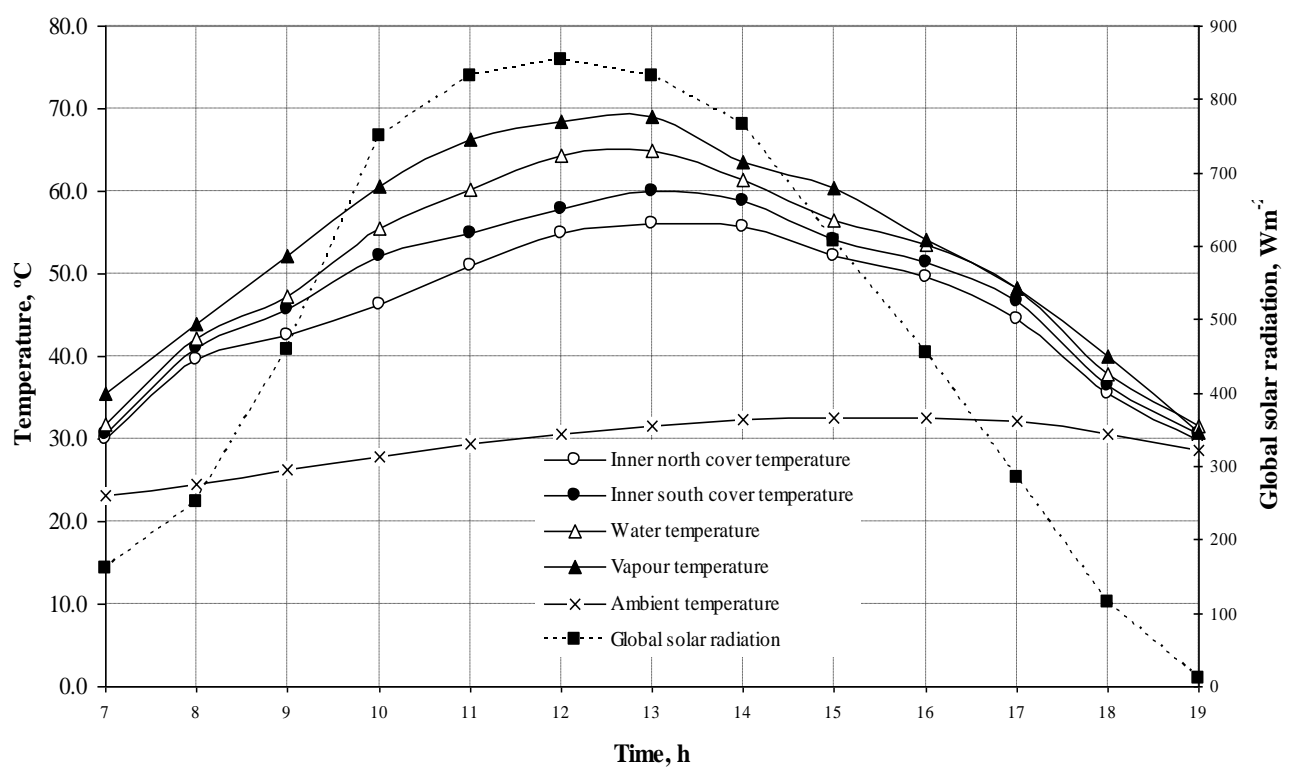

Fig. (3): Solar intensity and temperature variations of different components of solar still with shading.

The maximum distilled fresh water from southern cover was 311.3 and $310.2 \mathrm{ml}$ without and with shading covers, respectively. Whilst, the 
lowest distilled fresh water, respectively, were 28.8 and $23.2 \mathrm{ml}$. The maximum distilled fresh water from northern cover was 201.8 and 253.7 $\mathrm{ml}$, without and with shading covers, respectively. Wile, the lowest distilled fresh water was 10.2 and $10.7 \mathrm{ml}$, respectively.

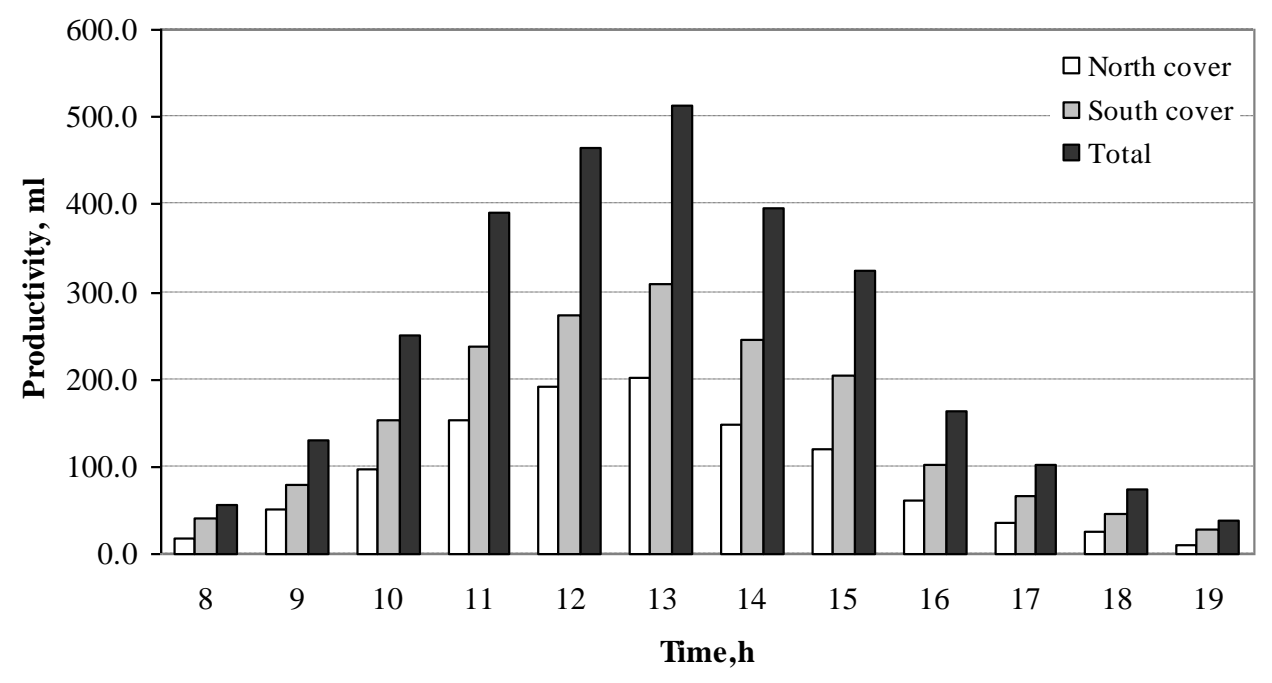

Fig. (4): Volumetric rates of distilled water of the solar still without shading.

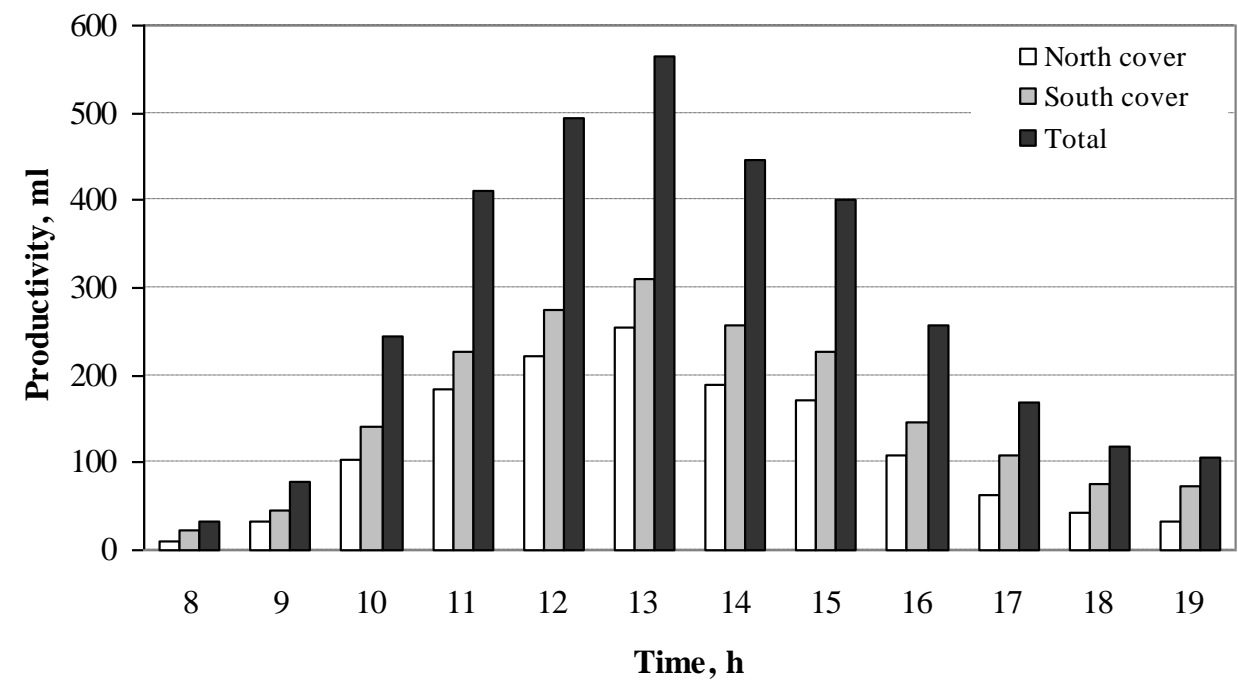

Fig. (5): Volumetric rates of distilled water of the solar still with shading. 
A comparison of the cumulative fresh water of the solar still with time for the first and second configurations is shown in Fig. (6). The enhancement in the thermal performance of solar still can be readily observed from the two curves plotted in the figure. Testing results indicated that, the daily accumulated distillated water of the solar still without and with shading reached approximately 3.3 and 2.9 1/day, respectively. The water productivity was enhanced by about $13.79 \%$ when the solar still was operated with shading the northern side.

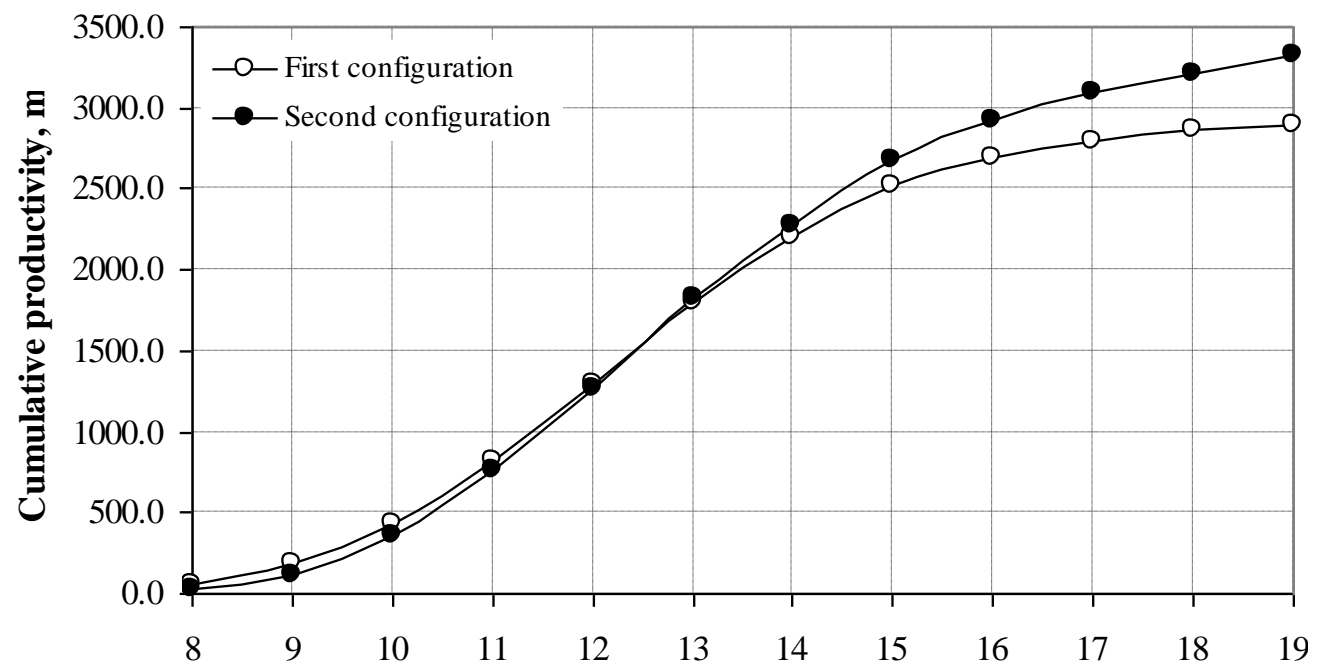

Time. $h$

Fig. (6): Cumulative fresh water of the solar still without and with shading.

The heat transfer from the water surface to the glass cover inside the solar still occurs in three different modes convection, radiation and evaporation. Fig. 7 shows the hourly average convective, radiative and evaporative heat transfer coefficients during the experimental work. In the solar still, the evaporative heat transfer coefficient $\left(\mathrm{h}_{\mathrm{e}, \mathrm{w}-\mathrm{g}}\right)$ had the greatest value as compared with the other two modes together. It was observed that the values of radiative heat transfer coefficient $\left(\mathrm{h}_{\mathrm{r}, \mathrm{w}-\mathrm{g}}\right)$ and convective heat transfer coefficient $\left(h_{c}, w-g\right)$ were lower than the evaporative heat transfer coefficient. Consequently, the operating water temperature was strongly dependent upon the evaporative heat transfer coefficient. It can also conclude that the maximum value of the heat 
transfer coefficient for convective, radiative and evaporative, respectively, was $2.2,7.6$ and $33.3 \mathrm{~W} / \mathrm{m}^{2} \mathrm{~K}$. Also it can be noticed that the maximum values of the three heat transfer coefficient were achieved afternoon (13:00 h).

As predicted by equations 1, 5 and 7, Fig. (8) reveals the variations in convection, evaporation and radiation heat transfer rate inside the still. It evidently shows that the heat transfer rate increased initially with respect to time. It reached the maximum values afternoon $(13: 00 \mathrm{~h})$ because the water temperature at this time was approached to the high level and accordingly, the heat transfer rate increased. Most of the incoming insolation was utilized for evaporation at this stage. The calculated heat transfer rate value was ranged between 1.8 and $23.3 \mathrm{Wm}^{-2}, 7.3$ and 341.5 $\mathrm{Wm}^{-2}$, and 9.2 and $70.6 \mathrm{Wm}^{-2}$ for convection, evaporation and radiation modes, respectively.

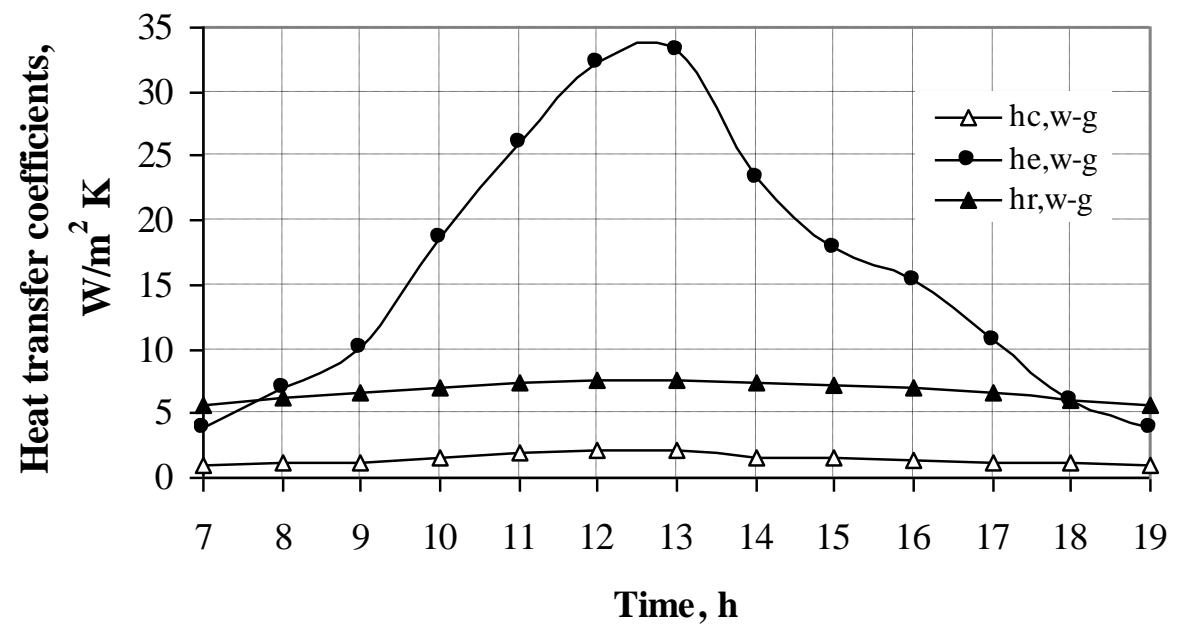

Fig. (7): Hourly average convective, radiative and evaporative heat transfer coefficients during the experimental work.

Fig. (9) shows the ratio between the evaporative heat transfers and the total heat transferred from the water to the cover (S-ratio) with respect to time. Computation of this ratio (S) dependent upon the basin's water and glass cover temperatures and was given by S-ratio $=\mathrm{q}_{\mathrm{e}, \mathrm{w}-\mathrm{g}} /\left(\mathrm{q}_{\mathrm{e}, \mathrm{w}-\mathrm{g}}+\mathrm{q}_{\mathrm{c}, \mathrm{w}-\mathrm{g}}\right.$ $+\mathrm{q}_{\mathrm{r}, \mathrm{w}-\mathrm{g}}$ ). The values of 'S-ratio' during the experimental work were ranged between 0.39 and 0.79 . 


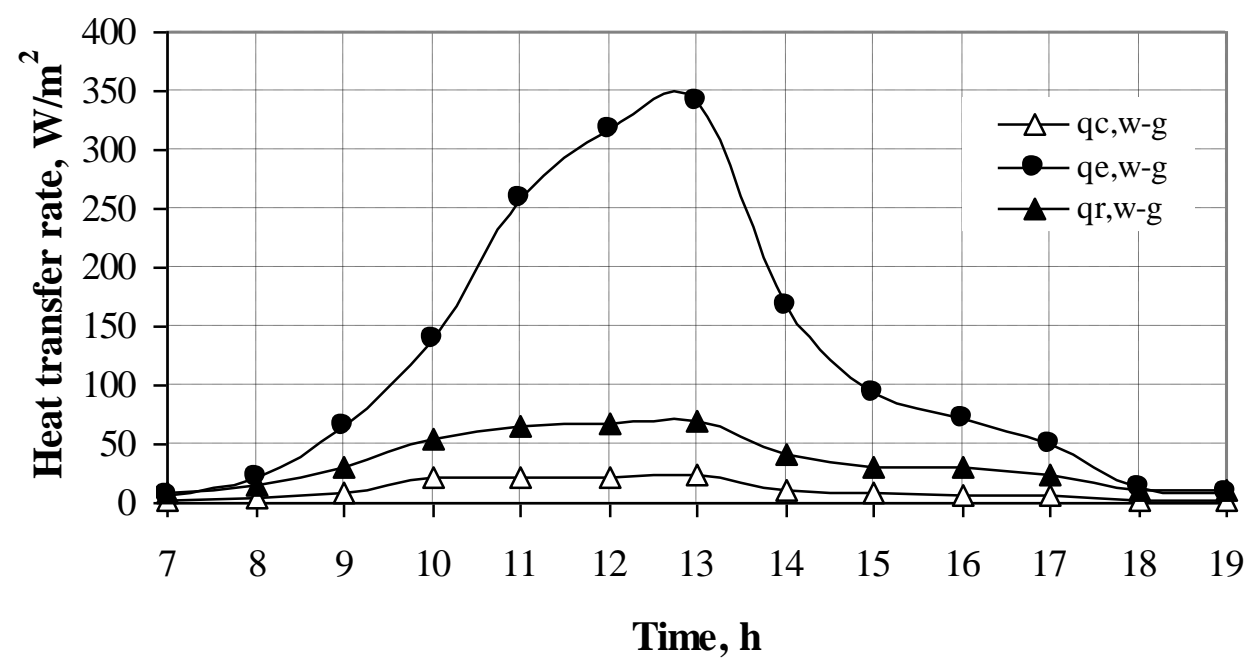

Fig. (8): Hourly average heat transfer rate by convection, radiation and evaporation inside the still.

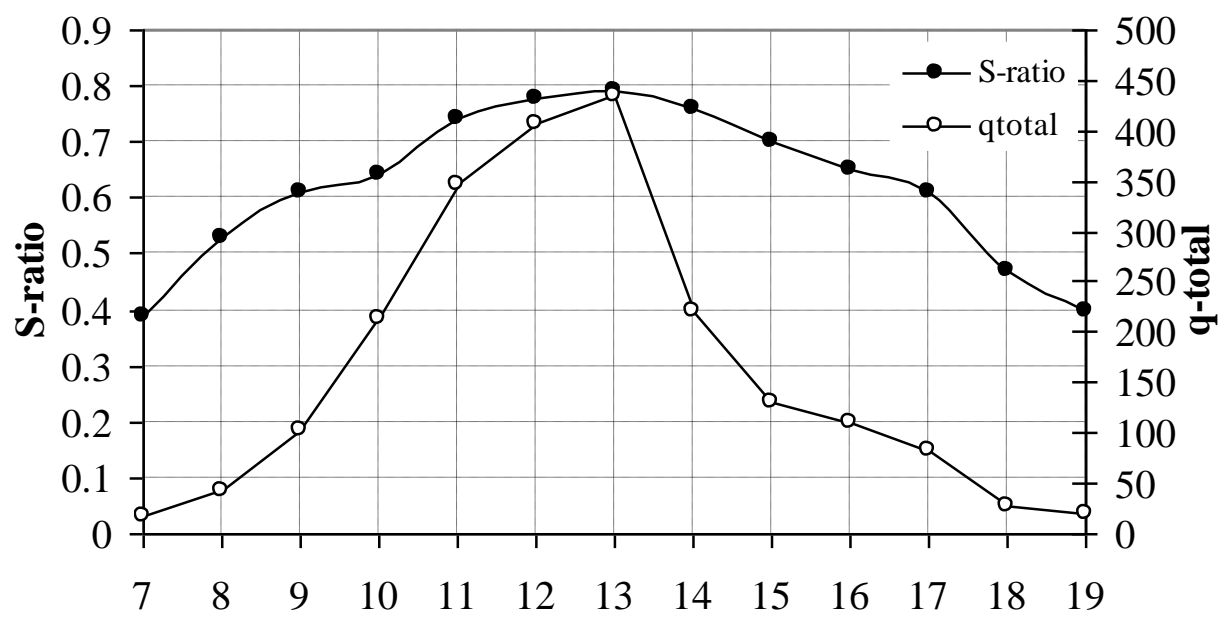

Time, h

Fig. (9): Hourly average S-ratio between the evaporative heat transfer and the total heat transferred from the water to the cover.

The hourly average heat losses by radiation and convection from glass cover to the ambient air is plotted in Fig. (10). It clearly shows that, the higher external losses occurred afternoon (at 13:00 h), since the 
temperature of the still components (basin's water and glass cover) was at high level at this time. The results showed that the total convection and radiation heat losses from glass cover to the ambient air were 1464.4 and $1681.2 \mathrm{~W} / \mathrm{m}^{2}$, respectively. It is also observed that the maximum amount of heat losses occured from the solar still was a combination of radiation and convection heat transfer from glass cover to the ambient air.

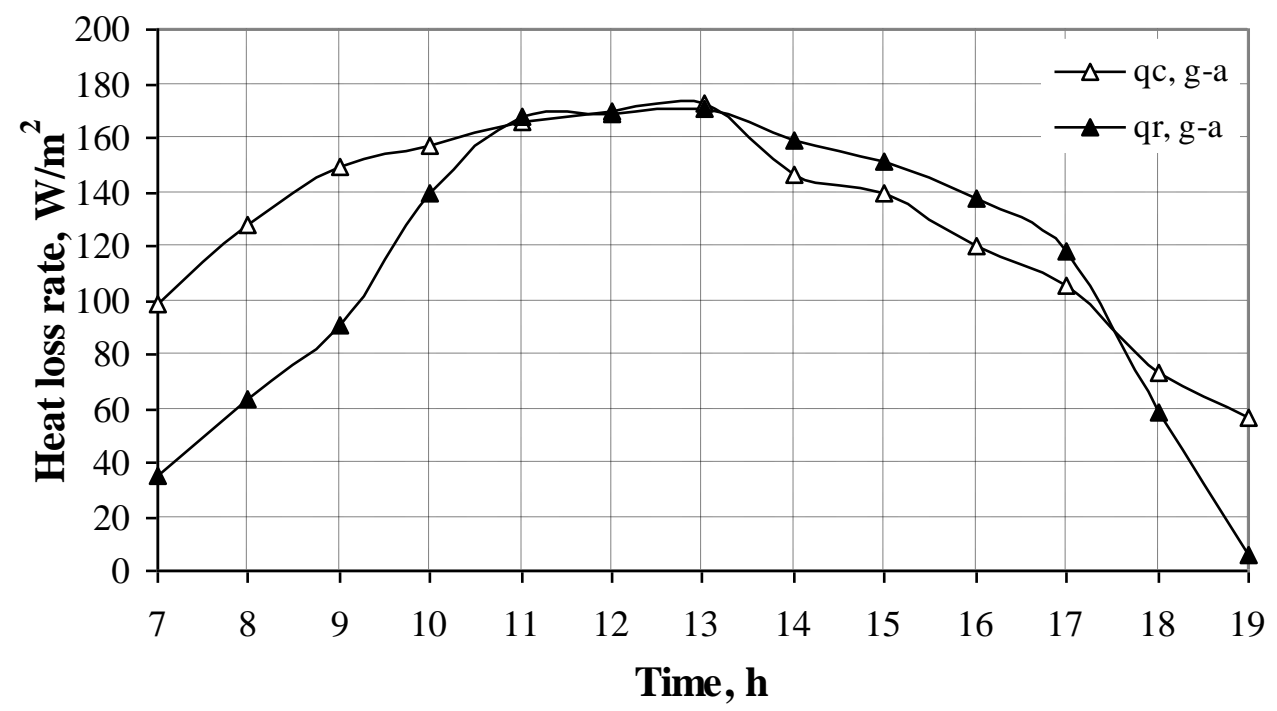

Fig. (10): Hourly variation of convection and radiation heat loss from glass cover to ambient.

\section{CONCLUSION}

A single basin asymmetrical double sloped solar still was tested to enhance the productivity of fresh water from the solar still by improving the thermal performance of its condenser. This was achieved by shading of the northern glass cover. It can be concluded that:

1. The second configuration produced an average of $13.79 \%$ more distillated water than the first configuration

2. The maximum value of the heat transfer coefficients for convective, radiative and evaporative, respectively, was 2.2, 7.6 and $33.3 \mathrm{~W} / \mathrm{m}^{2} \mathrm{~K}$. 
3. The maximum value of the heat transfer rates inside the still for convective, radiative and evaporative modes were 23.3, 70.6 and $341.5 \mathrm{~W} / \mathrm{m}^{2}$ respectively,

4. The maximum amount of heat losses from the solar still occurred by radiation and convection heat transfer from glass to ambient air.

\section{REFERENCES}

Al-Hayek I. and Badran O. (2004) "The effect of using different designs of solar stills on water distillation" Desalination, 169, 121127

Bahadori M. M. and Edlin F. E. (1973) "Improvement of solar stills by the surface transparency of the glass" Solar energy, 14, 339-352

Boukar, M. and Harim, A. (2003) "Development and testing of vertical solar still" Desalination, 158, 158-179

Cooper, PI. (1973) "The maximum efficiency of a single effect of solar stills" Solar Energy, 15, 3, 205-217

Duffie, J. A. and Beckman, W. A. (2006) "Solar Engineering of Thermal Processes" New York, N.Y., John Wiley and Sons, USA

Dunkle, R. V. (1961) "Solar water distillation, the roof type solar still and a multi effect diffusion still, International developments in heat transfer, ASME Proceedings of International Heat Transfer" University of Colorado. 5, 895-902.

El-Bahi, A. and Inan, D. (1999) "A solar still with minimum inclination, coupled to outside condenser" Desalination, 123, 79-83

Fath, E. S. and Hosny, H. M. (2002) "Thermal performance of a single-sloped basin still with an inherent built-in additional condenser" Desalination, 142, 19-27

Fath, H. E. S. (1998) "Solar desalination: a promising alternative for water provision with free energy, simple technology and a clean environment" Desalination, 116, 45-56

Fernandez, J. and Chargoy, N (1990) "Multi-stage, indirectly heated solar still" Solar Energy, 44 (4): 215-223 
Gracia-Rodriguez, L. (2004) "Desalination by wind power" Wind Engineering, 28, 453-466

Kabeel, A. E.; Omara, Z. M.; and Essa, F. A. (2014) "Enhancement of modified solar still integrated with external condenser using nanofluids: An experimental approach" Energy Conversion and Management, 78, 493-498

Malik, M. A.; Tiwar, G. N.; Kumar, A.; and Sodha, M. S. (1982) "Solar Distillation" Pergamon press Ltd, Oxford, UK.

McAdams, W. H. (1954) "Heat Transmission" $3^{\text {rd }}$ ed. McGraw-Hill Book Company, N.Y, USA

Rajaseenivasan, T.; Elango, T.and Mrugavel, K. K. (2013) Comparative study of double basin and single basin solar stills. Desalination, 309, 27-31

Taamneh, Y. and Taamneh, M. M. (2012) "Performance of pyramidshaped solar still: Experimental study" Desalination, 291, 65-68

Tiwari, G. N. (2002) "Solar Energy, Fundamentals, Designs, Modeling and Application" CRC press, New Delhi, Narosa Publishers, pp. 279-309

Tiwari, G. N. and Tiwari, A. K. (2008) "Solar distillation practice for water desalination systems" New Delhi, Anamaya Publishers.

Tiwari, G. N.; Dimri, V.; Singh, U.; Chel, A. and Sarkar, B. (2007) "Comparative thermal performance evaluation of an active solar distillation system" International Journal of Energy Research, 31, 1465-1482

Velmurugan, V. and Srithar, K. (2007) "Solar stills integrated with a mini solar pond-analytical simulation and experimental validation" Desalination, 216, 232-241

Zeroual, M.; Bouguettaia, H; Bechki D.; Boughali, S; Bouchekima B. and Mahcene, H. (2011) "Experimental investigation on a double slope solar still with partially cooled condenser in the region of Ouargla (Algeria)" Energy Proc., 6, 736-742 


\section{الملخص العربى}

\section{تأثير إستخدام التظليل علي آداء وإنتاجية وحدة تقطير شمسي ذات الميل من الجانبين تحث الظروف المناخية المصرية}

\section{إسلام حسن الثيخ"}

أجري هذا البحث بقسم الهندسـة الزر اعيـة ـ كليـة الزر اعـة ـ جامعة قنـاة السويس ـ الإسـماعيلية ويهدف إلي در اسة تأثير تظليل الجانب الثمالي لوحدة تقطير شمسي ذات الميل من الجانيين علي

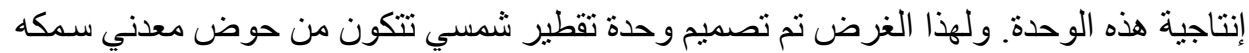

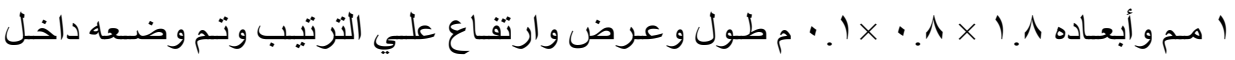

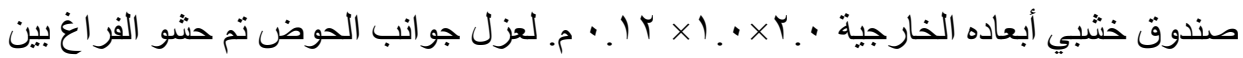

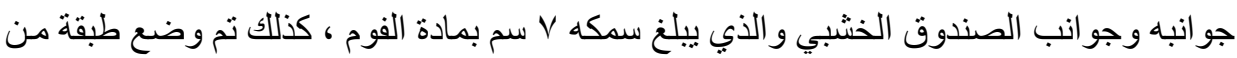

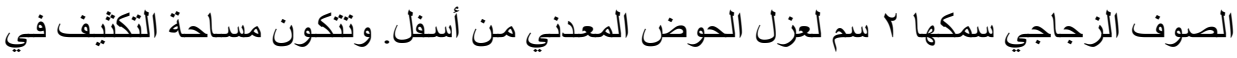

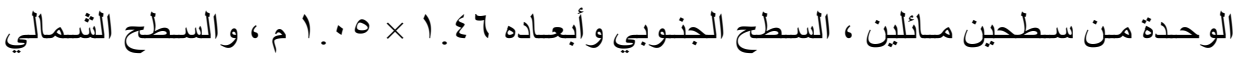

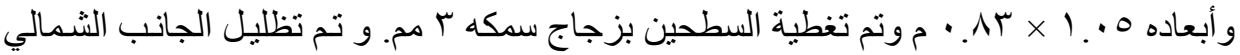

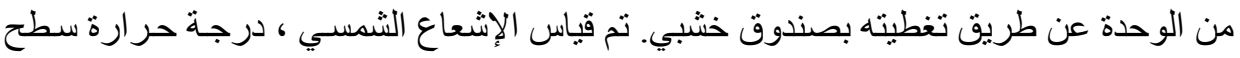

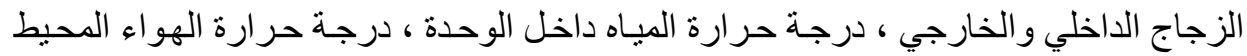

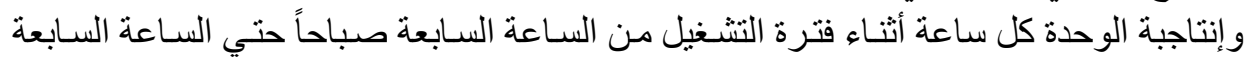
مساءً. و تم اختبار الوحدة مع نمطين للتشغيل هما:

$$
\begin{aligned}
& \text { 1 - تشغيل الوحدة بدون تظليل. } \\
& \text { r- تشغيل الوحدة مع تظليل الجانب الثمالي. } \\
& \text { وقد أوضحت النتائج ما يلي: }
\end{aligned}
$$

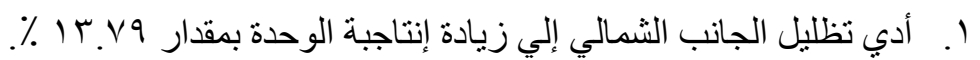

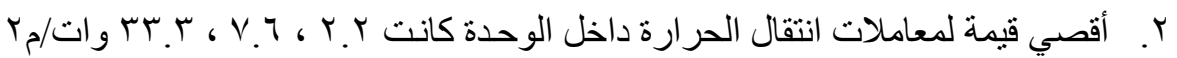
م م لكل من الحمل و الإشعاع و التبخير علي الترتيب.

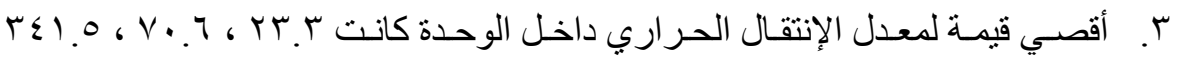
وات/مب لكل من الحمل والإشعاع و التبخير علي الترنتيب.

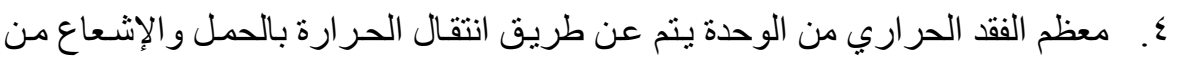
الغطاء الزجاجي إلي المحيط الخارجي.

* أستاذ مساعد ـ قسم الهندسة الزراعية ـ كلية الزراعة ـ جامعة قناة السويس. 